\title{
CONCEPTUAL APPROACHES TO THE DEVELOPMENT OF HEALTH-IMPROVING TOURISM
}

\author{
Olena Melikh ${ }^{1}$, Konstantin Bogatyrev ${ }^{2}$, Inna Irtyshcheva ${ }^{3}$
}

\begin{abstract}
The article highlights approaches to the development of health-improving tourism. The purpose of the article is to investigate medical and health tourism in Ukraine and to identify the preconditions for forming measures for further development. The subject-matter of the study is the theoretical and practical aspects of the development of health and wellness tourism in the country. In the course of the study, the following methods are used: dialectical, logical, and system approaches - to identify patterns and factors of development of health-improving tourism, graphical analysis - for the schematic representation of the generalized theoretical and practical results of the study, logical generalization of the results - to substantiate the main approaches to the development of health-improving tourism in the country. A healthy nation is a key to a successful country, therefore, studying the conceptual issues of ensuring and implementing methods of medical and recreational activities among the population is very relevant. Among the main methods of health-improving activities of people is tourism. An analysis is made among the main development indicators of health-improving tourism, where: during the study period, there was an increase in the number of subjects of tourist activities, including travel agents and subjects carrying out excursions, but negative is the reduction of tour operators; increase in the number of employed; increase in the number of tourists served by tourist enterprises; the average annual increase in the number of tourists, tourists traveling abroad, tourists within Ukraine. The number of places in the health-improving tourism establishments has decreased, while the servicing of visitors, on the contrary, has increased. Positive is the increase in the arrival of foreigners. There is justified the establishment of the central fund for the promotion of health-improving tourism development in order to increase the efficiency of state regulation, stimulate innovation-investment processes in health-improving tourism, which in turn will ensure an increase in the quality and standard of living of the population, which will lead to the sustainability of the socio-economic development of the state. The main goals and tasks of the central fund for the development of health-improving tourism are defined; directions of its activity and sources of financing are outlined. The work of the fund will enable intensifying tourist and sports activities in the country and increasing the efficiency of medicalrecreational processes of the population in the current conditions of integration.
\end{abstract}

Key words: medical and health services, health and wellness tourism, tourism activities, sports activities.

JEL Classification: G28, I15, L83

\section{Introduction}

Environmental pollution over industrial development causes a deterioration of public health. Therefore, today health-improving tourism occupies one of the leading places in the tourism industry because the active promotion of a healthy lifestyle, a slight increase in the profits of the inhabitants of economically developed countries makes many seek rehabilitation and rest in other, environmentally-friendly regions. Health and wellness tourism is based on the use of natural resources: mineral waters, medical mud, and climatic conditions, which, combined with each other, have a positive effect on the treatment of various diseases and give a corresponding result to health promotion. Ukraine has all the components for the development of health-improving tourism, namely: natural conditions, resources, development of resort infrastructure, use of modern methods of treatment, the attraction of foreign investments. Therefore, the issue arises as to the improvement of conceptual approaches to the development of health-improving tourism in Ukraine.

\footnotetext{
Corresponding author:

${ }^{1}$ Odessa National Academy of Food Technologies, Ukraine.

E-mail:melikh@gmail.com

${ }^{2}$ Admiral Makarov National University of Shipbuilding, Ukraine.

E-mail: bogatyrev@gmail.com

${ }^{3}$ Admiral Makarov National University of Shipbuilding, Ukraine.

E-mail: innauamd@gmail.com

ORCID: https://orcid.org/0000-0002-7025-9857
} 
The issue of organization of health-improving tourism and its place in the tourist industry system is disclosed in the works of foreign and domestic scholars. However, paying tribute to the results achieved, it is possible to identify a number of insufficiently worked out issues as regards to conceptual preconditions and factors for the development of health-improving tourism in the country.

Study of problems and prospects of the current state of health-improving tourism, as the main basis for the creation of conceptual approaches to development. Solving global problems with tourism development requires creating a model of tourism policy of the state. In the context of integration of tourist flows, there is a need to create a state authority that will provide the appropriate level of health-improving tourism in Ukraine.

\section{The essence and features of health-improving tourism}

According to M. Rutynskyi and V. Petranivskyi, the notion "health-improving tourism" does not have a clear interpretation. The simplest definition can be formulated as follows: health-improving tourism a trip to the resort areas for the purpose of recovery and treatment. The purpose of health-improving tourism is the complex use of natural healing factors and motor activity in therapeutic and prophylactic purposes. It is clear that medical and health tourism are often combined due to the similar purpose of travel and the realization of this goal on the basis of the use of one base (2012).

Health-improving tourism is divided into medical, the purpose of which is treatment as such, therapy, rehabilitation after illness, and preventive (wellness tourism), aimed at maintaining the body in a healthy condition and maintaining the balance between physical and psychological health. Wellness tourism, in turn, can be active (sports and fitness) and passive (beauty programs). The term "wellness" in the scientific literature has appeared relatively recently and it means a good state both of the body and soul, relaxation, the recovery of forces of the body through active wellness activities. If we proceed from the classification of travels, medical tourism can be conventionally attributed to special types of tourism, namely, tourism with therapeutic purposes. Such a definition includes not only trips to the resort but also other trips for the purpose of treatment, for example, for surgery in a foreign clinic (outbound tourism).

Recently, more and more foreign tourists (inbound tourism) are coming to Ukrainian resorts for treatment. Trips to the resort for a certain category of Ukrainian citizens are paid by the state (social tourism). The development of health-improving tourism in Ukraine is determined by the influence of various natural, historical, cultural, social, economic, political, and international factors. Moreover, the present-day specifics are that the formation of a highly developed tourism industry and its integration into the world market are related to the need to solve acute socio-economic problems during the transformation of socio-economic relations.

In order to analyse the level of functioning of the medical and healthcare industry in Ukraine, it is worth considering some indicators of international health and wellness tourism. International health and wellness tourism occupies a significant place both in the economy of individual countries and in the whole world.

In 2017, the direct, indirect, and mediated contribution of health and wellness tourism to the world economy was about $10.4 \%$ of GDP. This is stated in a press release by the World Travel and Tourism Council (WTTC). The organization conducted a study of the impact of tourism on the world economy in 185 countries of the world and concluded that tourism and related industries created $10.4 \%$ of world GDP or 8.3 trillion dollars. In addition, every tenth vacancy in the world is related to tourism, and in the sector as a whole - about 313 million jobs. The study also said that 2017 was one of the most successful for tourism in history. The tourist sphere has grown by $4.6 \%$, which exceeds world GDP growth (which is $3 \%$ ). According to the WTTC, the tourism industry has created about 7 million new jobs $-20 \%$ of all vacancies worldwide (Carenko, Shpak, 2014).

Relative indicators of the development of healthimproving tourism industry of Ukraine are more modest compared with the indicators of international tourism (Table 1). According to the data of the table, it is clear that the direct contribution of the tourism industry of Ukraine to the GDP formation in 2017 is estimated at 18.13 billion UAH, which is $0.6 \%$; according to the forecasts till 2022, this indicator should increase by only $294.37 \%$ - up to 71.5 billion UAH while the share remains unchanged.

With regard to employment, tourism attracts 10.29 thousand jobs, or $0.05 \%$, according to forecasts, these values will increase to 1368.8 thousand and 5.8\%.

In 2017, export earnings from international visitors amounted to $0.1 \%$ of the total exports ( 0.41 billion $\mathrm{UAH}$ ), and by 2022 their growth is expected to 59.2 billion UAH, which in turn will increase the indicator to $4.6 \%$.

The direct contribution of tourism to GDP is determined by the sum of income from foreign and domestic tourism, less the costs associated with the provision of tourism services.

As already noted, in health and wellness tourism, both direct and secondary results are quite clearly manifested. In particular, direct, indirect, and induced (derivative) economic consequences of tourism activity are allocated. Direct results are related to direct incomes of tourist enterprises. Indirect results relate to revenues from tourism in related industries, and the reason for the 
Vol. 5, No. 2, 2019

Baltic Journal of Economic Studies

Table 1

The main indicators characterizing the development

of the tourist industry of Ukraine in 2017 and the forecast for 2022

\begin{tabular}{|l|c|c|c|c|}
\hline \multirow{2}{*}{\multicolumn{1}{|c|}{ Indicators }} & \multicolumn{2}{|c|}{2017} & \multicolumn{2}{c|}{2022 (forecast) } \\
\cline { 2 - 5 } & $\begin{array}{c}\text { The absolute value in } \\
\text { the tourism industry }\end{array}$ & $\begin{array}{c}\text { Share to the } \\
\text { corresponding indicator } \\
\text { by country, } \%\end{array}$ & $\begin{array}{c}\text { The absolute value in } \\
\text { the tourism industry }\end{array}$ & $\begin{array}{c}\text { Share to the } \\
\text { corresponding indicator } \\
\text { by country, } \%\end{array}$ \\
\hline 1 & 2 & 3 & 4 & 5 \\
\hline $\begin{array}{l}\text { The direct contribution of the } \\
\text { tourism industry to GDP }\end{array}$ & 18,13 billion UAH & 0,6 & 71,5 billion UAH & 2,0 \\
\hline Number of jobs & 10,29 thousand & 0,05 & 1368,8 thousand & 5,8 \\
\hline Contribution to export earnings & 0,41 billion UAH & 0,1 & 59,2 billion UAH & 4,6 \\
\hline Contribution to import earnings & 0,57 billion UAH & 0,4 & 26,23 billion UAH & 2,3 \\
\hline Investment volume & 0,52 billion UAH & 0,2 & 16,7 billion UAH & 1,4 \\
\hline
\end{tabular}

Source: compiled according to the data (Official website of the State Statistics Service of Ukraine)

Table 2

The economic contribution of tourism to Ukraine's GDP

\begin{tabular}{|l|c|c|c|c|c|c|c|c|}
\hline \multicolumn{1}{|c|}{ Indicators } & 2011 & 2012 & 2013 & 2014 & 2015 & 2016 & 2017 \\
\hline \multicolumn{7}{|c|}{ The direct contribution of tourism, billion USD } \\
\hline Total revenue from tourism & 11,6 & 13,2 & 13,9 & 7,4 & 4,9 & 5,0 & 5,5 \\
\hline \multicolumn{7}{|c|}{ Other final consequences of tourism (indirect and induced), billion USD } \\
\hline Capital investment & 5,7 & 6,5 & 5,7 & 5,0 & 5,5 & 6,8 & 7,9 \\
\hline Public expenditures & 0,2 & 0,2 & 0,2 & 0,2 & 0,1 & 0,1 & 0,1 \\
\hline
\end{tabular}

Source: compiled according to the data from (Melnichenko, Shvedun, 2017)

emergence of induced results is the growth in demand for goods and services as a result of growth in volumes of medical and recreational activities. Therefore, in order to determine the real effectiveness of tourism, it is necessary to take into account its combined effect: direct, indirect, and induced.

Rest abroad since 2015 is becoming more popular and accessible among Ukrainians, and their expenditures are gradually reaching domestic consumption (the amount of expenses of domestic tourists and foreign visitors). In particular, the cost of compatriots on foreign holidays and travel since 2010 increased by 4.4 times, while travel across the country increased by only 2.5 times.

The total contribution of the tourism industry of Ukraine to GDP according to the WTTC in 2017 reached 147.2 billion UAH in nominal prices and has a steady growth trend; in particular, the direct contribution of the industry to GDP amounted to 39.6 billion UAH (Table 2).

As the data of Table 5 show, the direct contribution of tourism to GDP of Ukraine (by activities directly related to the provision of tourist services, in particular, tourist enterprises, hotels, airlines, and other companies providing passenger transport services, restaurants and recreational facilities working directly with tourists) during 2011-2013 has a rather dynamic growth: from 11.6 billion USD in 2011 to 13.9 billion USD in 2013, but after 2014 there is a sharp drop from 7.4 billion USD to 5.5 billion USD.

Despite some positive trends in the development of health and wellness tourism in Ukraine, there are a number of problems, namely:
1. A small number of medical and recreational enterprises due to significant barriers to entering the market for tourist services in Ukraine. The indicator of bed/population ratio of health-improving enterprises (the number of places per 1000 people) in Ukraine is low (with the norm of 10 places per 1000 people, there are only 2.9 hotel places in Ukraine).

2. Lack of a well-developed and officially accounted network of alternative means of accommodation of economy class.

3. Inconsistency of prices and the level of quality of medical and health services. The cost of living in Ukrainian health-improving enterprises is 2-3 times higher than the cost of living in hotels of a similar level in Europe.

4. Low level of competition of health-improving enterprises in the market over the lack of corporate standards for services quality management.

5. The underdevelopment of the network of tourist information centres, signposts, information facilities along the highways, which hinders the development of not only inbound but also domestic tourism.

6. Limited use of electronic and automated booking systems, which indicates a low level of tourist service culture.

7. Lack of Ukrainian tourist offices abroad.

8. Lack of funding and qualified specialists for the restoration of historical, cultural, and architectural monuments.

Thus, despite the negative phenomena that occur in the economy and society, the tourism industry is constantly 
increasing the volume of tourist products. According to the statistics, the results of the medical and healthcare industry in recent years show the development of this sphere and its positive tendencies.

\section{Conceptual approaches to the development of health and wellness tourism}

Best practices of state support to the socioeconomic development of the tourism industry, the implementation of which is seen as useful for Ukraine: - improvement of the legislative and regulatory framework for the activities of resorts, resort areas, and resort and tourist regions;

- expansion of the range and number of resort and tourist products;

- active introduction of management and marketing methods at resorts;

- creation of an alliance of Polish resorts;

- organization of the advertising campaign of resort and tourist regions (Borushchak, 2008);

- ensuring stable development rates of the national economy and real incomes of the population combined with controlled inflation and exchange rate changes;

- a powerful advertising campaign to popularize the country as a touristically attractive area;

- spreading of programs (including nutrition) "all inclusive";

- intensification of the development of the tourist cluster, which involves the integration of representatives of the tourism industry, science, education, public administration, local government, and public organizations;

- expansion of the range of tourist services and improvement of the national standard of their quality, in accordance with the modern market demands;

- provision of preferential loans for young people who are participants in educational and cultural tourism programs, as well as tax privileges for economic entities, who invest in the preservation and restoration of the historical and cultural heritage and the environmental state of recreational territories;

- declaring an open door policy, which cancels entry visas for tourists from a number of countries;

- organizational support for the development of objects of the tourism industry in depressed (including industrial) territories;

- simplification of land allocation procedures for new resorts and their connection to communications;

- maintenance of a favourable crime situation, as well as relatively low tourist expenses for transfers, meals, and accommodation;

- promoting the attraction of private investment and budget financing for the development of transport and social infrastructure (including taking into account the needs of persons with disabilities);

- creation of summer international camps, centres of ecological tourism (volunteer camps), summer universities and language schools, conducting international contests, competitions, festivals, etc. (Velichko, 2016).

It is appropriate to assume that the system of strategic state regulation of the development of the tourism industry is built in a certain sequence.

In particular, exclusively the system of state management strategies in the tourism industry consists of the following components:

- the strategy of development of the tourism industry of the national level;

- strategies for the development of certain industries which are a part of the tourism industry in the form of individual projects or target programs and provide an optimal solution to the systemic problem of tourism industry development;

- strategies and target programs for the development of the tourism industry of regions and cities, which should be built on the basis of the strategy of development of the nationwide tourism industry taking into account the specific properties of each separate territory.

In order to increase the efficiency of state regulation, stimulate investment activity, and increase the socioeconomic development of tourism in the country, we propose to establish a central fund for the promotion of health and wellness tourism development (Figure 1).

Regarding the sources of financing of the central fund for the promotion of health and wellness tourism, we identified the following:

- funds from the state, regional, and local budgets;

- private sector funds;

- funds of international technical assistance programs;

- funds of investors who will be involved in the realization of specific investment projects and implementation of programs;

- funds from international financial organizations (World Bank, International Monetary Fund, European Bank for Reconstruction and Development, European Investment Bank, etc.);

- funds from banks and non-bank financial institutions; - financial resources of commercial and non-commercial business entities, public associations, individuals, including foreign ones.

The expected results of the fund's activities are an increase in healthcare and investment activity, formation of a favourable tourist environment, achievement of sustainable economic growth in Ukraine, and increase in the standard of living and health of the population.

So, in our opinion, stabilization and revitalization of the state socio-economic development are impossible without radical changes in the role of tourism in the economic recovery. The current situation encourages the search for effective economic forms that would be able to radically and quickly change the situation in the country for the better. 


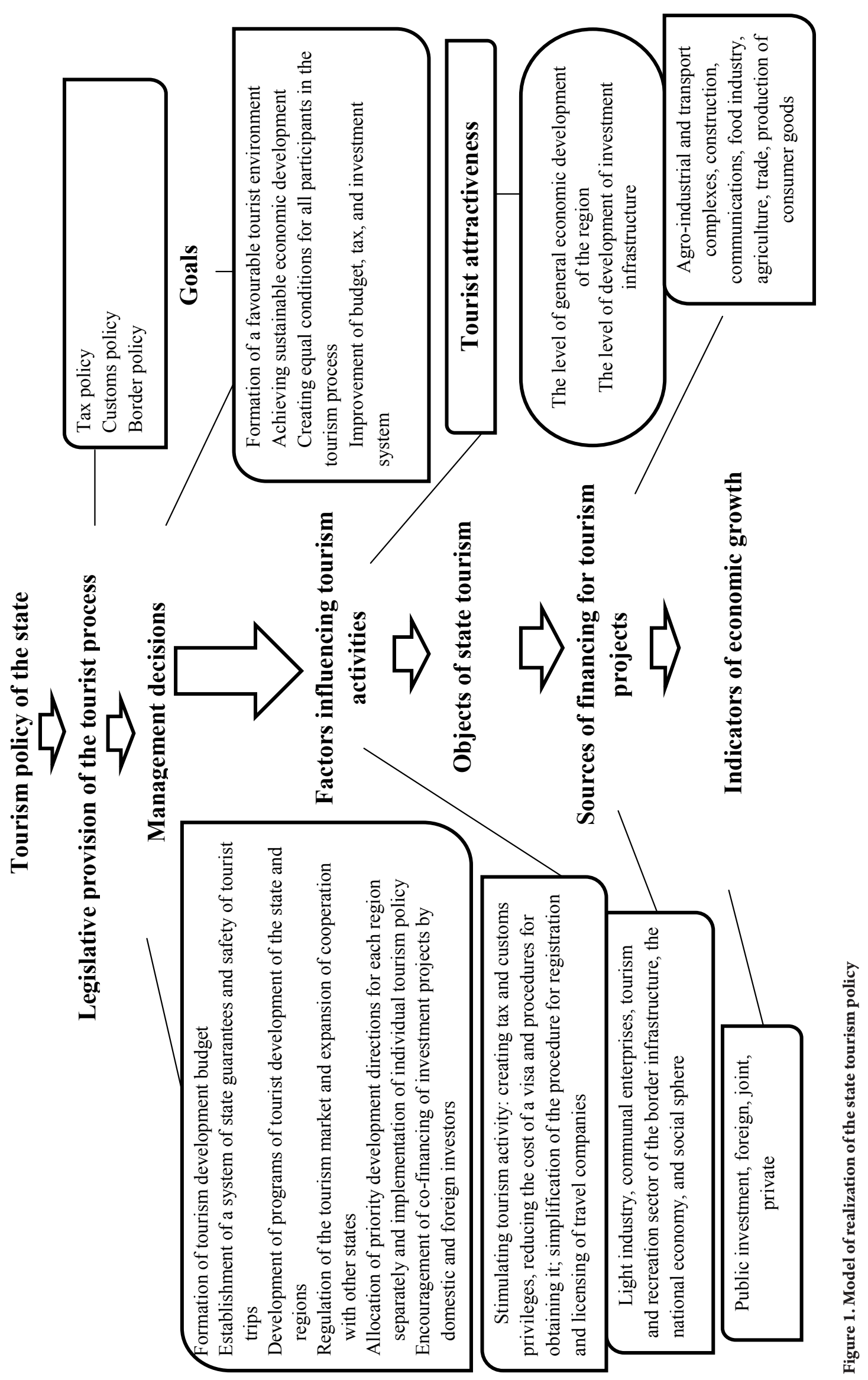




\section{Conclusions}

An analysis of the current state of development of health and wellness tourism has shown that during the study period, there was an increase in the number of subjects of tourist activities by $9.02 \%$, including travel agents by $10.01 \%$, and subjects carrying out excursion activities by $25.19 \%$; however, decrease in the number of tour operators by $0.4 \%$ is negative (this is the only indicator this year, which has a negative dynamics); increase in the number of employed by $7.33 \%$; increase in the number of tourists served by medical and recreational enterprises was $38.04 \%$; the average annual increase in the number of tourists servicing by $38.04 \%$, tourists traveling abroad by $39.61 \%$, and tourists within Ukraine by $33.59 \%$. The number of places in institutions decreased only in 2017 compared to 2016 by $1.85 \%$, and compared to 2015 it increased by $0.65 \%$. The service of visitors in institutions in 2017 increased by $51.32 \%$ compared to 2015 and by $50.10 \%$ compared to 2016 . Positive in 2017 is the increase of foreigners visiting our country by $149.45 \%$ compared to 2015 and by $91.30 \%$ compared to 2016.
At the same time, against the background of these growing indicators, there is an increase in the indicator of the quality of the load, it is quite high -32.42 in 2015 , 37.06 in 2016, and 38.50 in 2017, that is, the average level of loading of health-improving enterprises in Ukraine is only $385.0 \%$. Therefore, health and wellness tourism has a positive impact on the socio-economic development of the state, as foreign experience shows that $10 \%$ of world GDP is a contribution from tourism and related industries and $20 \%$ of job creation.

The establishment of a fund for the promotion of health-improving tourism development in order to increase the efficiency of state regulation and to stimulate health-improvement, tourism, and investment activity is substantiated, which will ensure the increase in the state socio-economic development and the strengthening of public health. The main goals and tasks of the central fund for the development of health-improving tourism are defined; directions of its activity and sources of financing are outlined. The work of the fund will enable intensifying health-improvement activities in the country and increasing the efficiency of the national economy in the current conditions of integration processes.

\section{References:}

Rutinskij, M., Petranivskij, V. (2012). Likuvalno-ozdorovchij turizm: aktualni cili ta suchasni pidhodi do organizacii [Therapeutic and health tourism: actual goals and modern approaches to the organization]. Visnyk of Lviv University. Series of international relations, 29, 179-189.

Borushchak, M. (2008). Strategiya rozvitku turistichnih regioniv: avtoref. dis. ... d.e.n.: spec. 08.00.05. Rozvitok produktivnih sil i regionalna ekonomika. Lviv.

Velichko, L. Yu. (2016). Peredovij svitovij dosvid derzhavnoi pidtrimki rozvitku turizmu: uroki dlya Ukrayni [Legal, managerial and economic aspects of the transformation of modern civil society]. Kyiv.

Donchenko, L. M., Gostieva, N. P. (2014). Problemi ta perspektivi derzhavnoi pidtrimki rozvitku turizmu [Problems and prospects of state support for tourism development]. State and regions. Series: Public Administration, 1, 37-42.

Zakon Ukraini «Pro turizm» [Law of Ukraine "On Tourism"]. Retrieved from: http://tourlib.net/zakon/pro_ turyzm.htm

Zaharchuk, S. (2014). Finansovo-ekonomichni problemi funkcionuvannya turistichnoi galuzi [Financial and economic problems of the tourism industry]. Economy. Management. Innovations Electronic Science. Professional Edition, 1(3). Retrieved from: http://www.nbuv.gov.ua

Melnichenko, O. A., Shvedun, V. O. (2017). Osoblivosti rozvitku industrii turizmu v Ukraïni [Features of the development of the tourism industry in Ukraine: monograph]. Kharkiv: View of NUTZU.

Mirovoj Atlas Dannyh [World Atlas of Data]. Retrieved from: https://knoema.ru/atlas/topics/ \%D0\%A2\%D1\%83\%D1\%80\%D0\%B8\%D0\%B7\%D0\%BC

Rogliev, H. J. (2005). Silskij turizm - perspektivnij napryamok rozvitku turistskoi industrii Ukraini [Rural tourism is a perspective direction of development of the tourist industry of Ukraine]. Scientific and Practical Journal "Tourism: Theory and Practice, 1, 43-48.

Savicka, O. P., Savicka, N. V. (2013). Strategiya rozvitku turistichnoi industriï v Ukraini: regionalni aspekti [Strategy for the development of tourist institution in Ukraine: regional aspects]. Bulletin of the National University "Lviv Polytechnic". (Series "Problems of Economics and Management"), 754, 68-74.

Smolii, V. A. Fedorchenko, V. K., Tsybukh, V. I. (2006). Entsyklopedychnyi slovnyk-dovidnyk z turyzmu [Encyclopaedic Dictionary of Tourism]. Kyiv: Publishing House "Slovo".

Official website of the State Statistics Service of Ukraine. Retrieved from: http://www.ukrstat.gov.ua/

Carenko, O. V., Shpak, L. O. (2014). Rozrobka mekhanizmu zaluchennya finansovih investicij v turistichnorekreacijnij kompleks regionu [Development of the mechanism of attraction of financial investments in the touristrecreational complex of the region]. Investments: practice and experience, 6, 11-14.

Chekalyuk, V. V. (2014). Turizm yak chinnik formuvannya derzhavnogo imidzhu [Tourism as a factor in the formation of a state image]. Information Society, 19, 13-16.

Gaworecki, W. W. (2000). Turystyka. Warszawa: Polskie Wydawnictwo Ekonomiczne. 